\title{
EFEKTIVITAS MODEL PEMBELAJARAN TIPE GROUP INVESTIGATION (GI) \\ DAN COOPERATIVE INTEGRATED READING AND COMPOSITION (CIRC) DALAM MENINGKATKAN KREATIVITAS BERPIKIR KRITIS DAN HASIL BELAJAR IPS SISWA KELAS 4
}

\author{
Lucia Venda Christina \\ Firosalia Kristin \\ PGSD FKIP Universitas Kristen Satya Wacana \\ luciavendachristina@gmail.com \\ firosalia.kristin@gmail.com
}

\begin{abstract}
ABSTRAK
Tujuan penelitian ini untuk mengetahui efektivitas model pembelajaran kooperatif tipe $G I$ dan CIRC dalam meningkatkan kreativitas berpikir kritis dan hasil belajar IPS siswa kelas 4 SDN Gendongan 02 Salatiga. Jenis penelitan adalah eksperimen. Subyek pada penelitian ini adalah siswa kelas 4 SDN Gendongan 02 yang berjumlah 37 siswa dan siswa kelas IV SDN Sidorejo Kidul 02 yang berjumlah 35 siswa. Metode pengumpulan data dengan menggunakan tes untuk mengetahui hasil belajar dan rubrik untuk mengetahui kreativitas berpikir kritis siswa. Metode analisis data dengan melakukan uji t. Berdasarkan hasil uji t diperoleh data nilai $\mathrm{t}$ hitung $=5,722$ dan $\mathrm{t}$ tabel $=0,05$ dengan signifikansi pada uji $\mathrm{t}$ adalah $0,000<0,05$ maka terdapat perbedaan rata-rata antara kelas eksperimen dan kelas kontrol. Pada analisis penilaian kreativitas berpikir kritis siswa didapat peningkatan dari rata-rata 28,05 menjadi 29,32. Dari hasil penelitian dapat disimpulkan bahwa penerapan model pembelajaran kooperatif tipe GI dan CIRC efektif dalam meningkatkan kreativitas berpikir kritis siswa, serta dapat meningkatkan hasil belajar IPS siswa kelas 4 SDN Gendongan 02. Saran bagi guru hendaknya menggunakan model pembelajaran kooperatif yang dapat disesuaikan dengan materi yang akan diajarkan, bagi siswa hendaknya lebih aktif dalam mengikuti pelajaran, bagi sekolah supaya menyediakan sarana dan prasarana yang diperlukan untuk pembelajaran, dan bagi pembaca yang akan melakukan penelitian dengan model pembelajaran yang sama hendaknya guru yang menentukan setiap anggota kelompok sehingga waktu untuk pembentukan kelompok tidak terlalu banyak.
\end{abstract}

Kata kunci: Model GI dan CIRC, Kreativitas Berpikir Kritis, Hasil Belajar.

\section{PENDAHULUAN}

Pendidikan merupakan suatu hal yang penting dalam kehidupan dan bentuk dari perubahan manusia. Dalam dunia pendidikan terdapat wadah untuk melaksanakan serangkaian kegiatan belajar mengajar melalui sekolah termasuk kegiatan belajar mengajar di dalam kelas.

Pembelajaran IPS di sekolah dasar diharapkan dapat menjadi wahana atau tempat bagi siswa untuk mempelajari diri sendiri dan lingkungan sekitarnya. Lingkungan sekitar meliputi keberagaman suku, bahasa, agama, dan sebagainya. Siswa dapat mempelajari diri sendiri dengan menentukan sikap mereka terhadap lingkungan sekitarnya dan bagaimana harus bertindak di lingkungan sosialnya. Siswa dapat belajar tentang lingkungan sekitar dan lingkungan sosial melalui pembelajaran IPS di sekolah serta dapat mempelajarinya dalam kehidupan sehari-hari.

Pembelajaran IPS di SD hendaknya dipelajari sesuai dengan perkembangan karakteristik siswa sehingga mereka mampu menerapkan yang sudah dipelajari di dalam kehidupan mereka seharihari. Pembelajaran tersebut lebih mengutamakan keaktifan siswa sehingga siswa dapat mengkonstruk sendiri ilmu pengetahuan yang mereka dapatkan. Dari observasi di kelas 4 SDN GENDONGAN 02, pembelajaran IPS lebih banyak menggunakan metode ceramah, setelah guru selesai menyampaikan 
Efektivitas Model Pembelajaran Tipe Group Investigation (GI) Dan Cooperative Integrated Reading And Composition (CIRC) Dalam Meningkatkan Kreativitas Berpikir Kritis Dan Hasil Belajar IPS Siswa Kelas 4 (Lucia Venda Christina, Firosalia Kristin)

materi selanjutnya siswa diminta untuk mengerjakan soal-soal LKS. Berdasarkan wawancara dengan guru kelas 4 SDN GENDONGAN 02 Salatiga, beliau menyatakan bahwa masih banyak siswa yang malas membaca untuk menemukan pokok pembahasan pada pelajaran IPS maupun pelajaran yang lain. Pada saat guru menyampaikan dan menjelaskan materi pembelajaran dengan berceramah, hanya beberapa siswa yang memperhatikan dengan baik, dan siswa yang lain justru berbicara dengan teman satu bangkunya. Terbukti dari nilai LKS dan nilai ulangan harian, siswa yang telah mencapai KKM yaitu 65 hanya 25 siswa (66\%) dari keseluruhan peserta didik yang berjumlah 38 siswa, dan sebanyak 13 siswa (34\%) belum mencapai KKM. Maka dari itu untuk mengatasi permasalahan tersebut guru harus mencari model pembelajaran yang menyenangkan dan menerapkannya dalam pelajaran IPS sehingga minat belajar siswa tumbuh dan siswa tidak bosan ketika pelajaran berlangsung. Minat belajar siswa perlu dipupuk agar siswa dapat belajar dengan nyaman dan dapat menyerap materi yang diberikan oleh guru dengan baik. Jika siswa telah memiliki minat belajar yang besar maka siswa akan dapat mengikuti pelajaran dengan baik sehingga siswa dapat berpikir kritis mengenai materi yang ditangkap dan akan berpengaruh pada hasil belajarnya.

Model dalam pembelajaran yang inovatif harus dipilih dan diterapkan guru sesuai dengan materi yang akan diajarkan. Model pembelajaran kooperatif tipe Group Investigation (GI) dan tipe Cooperative Integrated Reading and Composition (CIRC) dapat digunakan dalam pembelajaran IPS. Model pembelajaran kooperatif tipe Group Investigation (GI) merupakan model pembelajaran yang mendukung terjadinya dialog antara siswa satu dengan siswa lain yang akan mengacu pada aspek sosial afektif. Aspek sosial afektif dalam bekerjasama dengan kelompok, pertukaran pengetahuan/ide, dan materi yang dibahas merupakan beberapa hal penting untuk mendukung kegiatan siswa dalam belajar dengan menggunakan model pembelajaran Group Investigation (GI). Komunikasi antar siswa yang bersifat kooperatif dapat berlangsung dengan baik apabila dilaksanakan melalui kelompokkelompok kecil dalam belajar. Model pembelajaran Group Investigation (GI) tepat untuk mata pelajaran yang memerlukan kegiatan terintegrasi serta mengarah pada kegiatan memperoleh informasi dalam upaya memecahkan permasalahan yang dihadapkan pada siswa.

Model pembelajaran kooperatif tipe Cooperative Integrated Reading and Composition $(C I R C)$ merupakn model pembelajaran yang bertujuan untuk melatih kemampuan siswa secara terpadu antara membaca dan menemukan ide pokok suatu wacana/materi dan memberikan tanggapan secara tertulis. Melalui model tersebut pembelajaran IPS yang tadinya dianggap membosankan dan banyak teori dapat dipelajari dengan mudah dan lebih menyenangkan. Model pembelajaran ini akan melatih siswa untuk mampu berpikir kritis dengan membaca untuk menemukan ide pokok dari suatu wacana/materi. Pembelajaran dengan menggunakan model Cooperative Integrated Reading and Composition (CIRC) dilakukan dengan cara membentuk kelompok agar siswa mampu bekerjasama dengan teman satu kelompoknya untuk menemukan suatu ide pokok suatu materi. Setiap anggota kelompok menyampaikan ide/gagasannya mengenai suatu materi yang sedang dibahas dan saling bertukar pendapat untuk menyelesaikan tugas kelompoknya.

Proses pembelajaran di dalam maupun di luar kelas akan berlangsung dengan baik apabila guru dan siswa berkomunikasi dengan baik pula. Dalam pembelajaran siswa akan mendapatkan hasil yang memuaskan jika siswa dapat menangkap dan mencerna materi yang diberikan oleh guru. Dengan kemampuan berpikir yang kreatif dan kritis siswa akan mencerna materi yang didapat dengan baik, dan hasil belajarnya akan memuaskan. Menurut Sujanto (2001:56) berpikir ialah menetapkan hubungan-hubungan antara pengetahuan-pengetahuan kita, berpikir merupakan suatu proses dialektis artinya selama berpikir pikiran kita mengadakan tanya jawab untuk dapat meletakkan hubunganhubungan antara pengetahuan kita dengan tepat. Kemampuan berpikir yang kreatif sudah dimiliki oleh semua orang sejak mereka lahir. Menurut Munandar (1999:12) biasanya anak yang kreatif 
memiliki rasa ingin tahu yang besar, memiliki minat yang luas dan menyukai aktivitas yang kreatif. Maka kreativitas berpikir kritis siswa pada pelajaran IPS dapat ditingkatkan melalui pembelajaran yang menarik dengan menggunakan model pembelajaran yang tepat sehingga siswa memiliki rasa ingin tahu yang besar. Kreativitas yang dimiliki oleh siswa akan muncul sesuai dengan permasalahan yang dihadapi oleh siswa. Pembelajaran IPS yang dilaksanakan dengan menggunakan model pembelajaran Group Investigation (GI) dan Cooperative Integrated Reading and Composition (CIRC) akan membantu siswa untuk belajar IPS dengan senang dan menumbuhkan kreativitas berpikir kritis untuk menemukan ide/pokok suatu materi secara mandiri dan berkelompok.

Berdasarkan latar belakang masalah yang dijabarkan, maka rumusan masalah dalam penelitian ini adalah; (1) Efektivitaskah penerapan model pembelajaran kooperatif tipe Group Investigatin (GI) dan Cooperative Integrated Reading and Composition (CIRC) dalam meningkatkan kreativitas berpikir kritis siswa kelas 4 SDN GENDONGAN 02 Salatiga Tahun Ajaran 2015/2016? (2) Efektivitaskah penerapan model pembelajaran kooperatif tipe Group Investigatin (GI) dan Cooperative Integrated Reading and Composition (CIRC) dalam meningkatkan hasil belajar IPS siswa kelas 4 SDN GENDONGAN 02 Salatiga Tahun Ajaran 2015/2016?

\section{KAJIAN PUSTAKA}

\section{Ilmu Pengetahuan Sosial}

Ilmu Pengetahuan Sosial (IPS) merupakan mata pelajaran yang mengkaji fakta, konsep, dan peristiwa yang terjadi dalam masyarakat. Suwarso dan Widiarso (2007:1) mengemukakan bahwa IPS adalah program pendidikan yang mengintegrasikan secara interdisiplin konsep ilmu-ilmu sosial and humaniora. Ilmu pengetahuan lahir dari keinginan para pakar pendidikan untuk membekali para siswa supaya nantinya mereka mampu menghadapi dan menangani kompleksitas kehidupan di masyarakat yang seringkali berkembang secara tidak terduga.

Menurut Sumaatmadja (1980:22) pengajaran IPS hakekatnya adalah pengajaran interelasi aspek-aspek kehidupan manusia di masyarakat. Pengajaran IPS merupakan sistem pengajaran yang membahas-menyoroti-menelaah-mengkaji gejala atau masalah sosial dari berbagai aspek kehidupan, atau melakukan interelasi berbagai aspek kehidupan sosial dalam membahas gejala atau masalah sosial.

IPS merupakan kombinasi atau hasil pemfusian atau perpaduan dari sejumlah mata pelajaran seperti: geografi, ekonomi, sejarah, sosiologi, politik (Saidiharjo, 1996:4). Tim IKIP Surabaya mengemukakan bahwa IPS merupakan bidang studi yang menghormati, mempelajari, mengolah, dan membahas hal-hal yang berhubungan dengan masalah-masalah human relationship hingga benarbenar dapat dipahami dan diperoleh pemecahannya. Penyajiannya harus merupakan bentuk yang terpadu dari berbagai ilmu sosial yang telah terpilih, kemudian disederhanakan sesuai dengan kepentingan sekolah-sekolah.

Berdasarkan uraian di atas dapat disimpulkan bahwa IPS bukanlah ilmu sosial dan pengajaran IPS di sekolah dasar tidak menekankan pada teori keilmuan sosial tetapi lebih menekankan pada aspek praktis dalam mempelajari, menelaah, mengkaji gejala, dan masalah sosial masyarakat yang sesuai dengan jenjang pendidikan.

\section{Hakikat Ilmu Pengetahuan Sosial}

Pada hakikatnya IPS adalah telaah tentang manusia dan dunia/lingkungannya. Dalam hidupnya manusia selalu hidup bersama dengan manusia lain sebagai makhluk sosial yang tidak dapat hidup sendiri. Melalui pelajaran IPS peserta didik diperkenalkan pada lingkungan serta rasa tanggung 
jawab sosial. IPS merupakan perpaduan berbagai cabang ilmu sosial diantaranya sejarah, sosiologi, psikologi, ekonomi, politik, geografi, antropologi, dan sebagainya. Hakekatnya bidang-bidang ilmu sosial yang dirangkum dalam pembelajaran di sekolah dasar sama-sama mempelajari bidang kehidupan manusia di masyarakat, mempelajari gejala dan masalah sosial yang menjadi bagian dari kehidupan.

Dari uraian di atas dapat disimpulkan bahwa hakekat IPS ialah kehidupan manusia serta lingkungannya yang dapat disampaikan pada pembalajaran. Penyampaian materi IPS dapat dirangkum dan di sesuaikan dengan jenjang pendidikan sehingga rangkuman ilmu sosial yang sampaikan pada bangku sekolah akan berbeda disetiap jenjangnya.

\section{Tujuan Ilmu Pengetahuan Sosial}

Tujuan mata pelajaran IPS di sekolah dasar yaitu untuk menguasai konsep dan manfaat IPS dalam kehidupan sehari-hari serta untuk melanjutkan pendidikan ke Sekolah Menengah Pertama atau Madrasah Tsanawiyah. Fungsi dan tujuan mata pelajaran IPS yang tercantum dalam kurikulum IPS (2006) yaitu: (a) membekali peserta didik dengan pengetahuan sosial yang berguna dalam kehidupan bermasyarakat, (b) membekali peserta didik dengan kemampuan mengidentifikasi, menganalisa, dan menyusun alternative pemecahan masalah sosial yang terjadi dalam kehidupan di masyarakat, (c) membekali peserta didik dengan kemampuan berkomunikasi dengan sesama warga masyarakat dan berbagai bidang keilmuan serta berbagai keahlian, (d) membekali peserta didik dengan kesadaran, sikap mental yang positif, dan keterampilan terhadap lingkungan hidup yang menjadi bagian kehidupannya yang tidak terpisahkan, dan (e) membekali peserta didik dengan kemampuan mengembangkan pengetahuan dan keilmuan IPS sesuai dengan pertimbangan kehidupan.

Berdasarkan penyataan di atas, dapat disimpulkan bahwa Ilmu Pengetahuan Sosial (IPS) bertujuan untuk membekali peserta didik dengan pengetahuan yang dapat diperoleh pada bangku pendidikan, sehingga mampu mengetahui masalah sosial yang ada disekitarnya dan mampu menemukan pemecahan masalah dan tindakan yang harus dilakukan untuk menghadapi masalah tersebut agar tercipta komunikasi dengan warga masyarakat yang ada disekitarnya.

\section{Ruang Lingkup Ilmu Pengetahuan Sosial}

Ruang lingkup mata pelajaran IPS meliputi aspek-aspek: (a) manusia, tempat, dan lingkungan, (b) waktu, keberlanjutan, dan perubahan, (c) system sosial dan budaya, (d) perilaku ekonomi dan kesejahteraan. Maka dapat disimpulkan bahwa ruang lingkup IPS adalah manusia itu sendiri beserta lingkungan, waktu, dan sosial budaya dilingkungannya. Ruang lingkup mata pelajaran IPS di sekolah dasar berbeda pada tiap tingkat kelasnya. Dimulai dari ruang lingkup yang paling sederhana pada kelas satu, selanjutnya menjadi lebih luas di tingkat yang lebih tinggi.

\section{Pembelajaran IPS SD}

Pelajaran Ilmu Pengetahuan Sosial, disingkat IPS, merupakan nama mata pelajaran di tingkat sekolah dasar dan menengah atau nama program studi di perguruan tinggi identik dengan istilah "social studied". Pengertian IPS di sekolah dasar merupakan nama mata pelajaran yang berdiri sendiri sebagai integrasi dari sejumlah konsep disiplin ilmu sosial, humaniora, sains bahkan berbagai isu dan masalah sosial kehidupan. Pembelajaran IPS di sekolah dasar yang lebih menekankan kepada aspek pendidikan diharapkan siswa dapat memperoleh pemahaman tentang beberapa konsep sosial dan dapat melatih sikap, moral, dan keterampilan berdasarkan konsep yang telah dimiliki dan dipahami tersebut. Maka dapat disimpulkan bahwa pembelajaran IPS adalah suatu proses belajar yang 
mengintegrasikan konsep-konsep dari berbagai ilmu sosial agar siswa mampu memahami masalah sosial dan bersikap sesuai konsep yang telah dimiliki.

\section{Pengertian Model Pembelajaran Group Investigation (GI) dalam Pembelajaran IPS}

Model pembelajaran Group Investigation (GI) dimulai dengan membagi siswa menjadi beberapa kelompok belajar. Selanjutnya guru memberikan topik/pokok masalah yang akan dibahas, siswa diminta untuk bekerjasama dengan kelompok masing-masing. Penggunaan metode Group Investigation setiap kelompok akan bekerja untuk melakukan investigasi sesuai dengan masalah yang mereka pilih (Suprijono, 2011:6).

Sesuai dengan pengertian-pengertian tersebut maka dapat diketahui bahwa pembelajaran dengan metode Group Investigation adalah pembelajaran yang melibatkan aktivitas siswa yang akan membuat siswa lebih bersemangat untuk mengikuti pembelajaran dan dapat belajar dengan senang.

\section{Langkah-langkah Pembelajaran Group Investigation}

Langkah-langkah pembelajaran dengan menggunakan model pembelajaran Group Investigation yaitu pembentukan kelompok, menentukan tema yang akan di bahas, melakukan investigasi antar anggota kelompok untuk menemukan pokok pikiran dari suatu bacaan, setiap kelompok menyiapkan laporan tertulis, presentasi oleh setiap kelompok berdasarkan laporan yang telah dibuat, evaluasi/penilaian dari guru maupun dari siswa yang berasal dari kelompok lain.

\section{Kelebihan dan Kelemahan Model Pembelajaran Group Investigation}

Kelebihan model Group Investigation yaitu dapat meningkatkan kemampuan berpikir tingkat tinggi dan keterampilan inkuiri kompleks. Kegiatan dalam pembelajaran berfokus pada siswa sehingga pengetahuannya benar-benar diserap dengan baik. Pembelajaran dengan menggunakan model ini dapat meningkatkan keterampilan sosial dimana siswa dilatih untuk bekerja sama dengan siswa lain, meningkatkan pengembangan softskills (kritis, komunikatif, kreatif) dan group process skill (menejemen kelompok).

Kelemahan Group Investigation yaitu memerlukan struktur kelas yang lebih rumit, pendekatan pada model ini mengutamakan keterlibatan siswa dalam bertukar pikiran, sehingga tujuan pembelajaran tidak akan tercapai pada siswa yang tidak turut aktif, memerlukan waktu belajar yang lebih lama, memerlukan waktu untuk penyesuaian sehingga suasana kelas mudah ribut/gaduh. Solusinya ketika membagi kelompok perlu diperhatikan karakteristik siswanya supaya yang kurang aktif tidak semuanya jadi satu kelompok.

\section{Model Pembelajaran Cooperative Integrated Reading and Composition (CIRC) dalam Pembelajaran IPS}

Pembelajaran kooperatif merupakan model pembelajaran dengan menggunakan sistem pengelompokan/tim kecil, yaitu antara empat sampai enam orang yang mempunyai latar belakang yang kemampuan akademik, jenis kelamin, ras, atau suku yang berbeda/heterogen (Sanjaya, 2011:242). Pembelajaran dengan menggunakan model pembelajaran CIRC menekankan pada kemampuan membaca kelompok untuk menemukan ide suatu wacana/materi dari topik pembelajaran yang sedang dibahas. Seluruh siswa dalam kelompok belajar harus terlibat dalam kegiatan belajar kelompok, terutama siswa harus terlibat membaca dalam kelompok yang bertujuan untuk menemukan ide dari suatu materi pembelajaran yang sedang dibahas, sehingga siswa mampu memahami topik tersebut dan mampu berpikir kritis.

\section{Langkah-langkah Pembelajaran Cooperative Integrated Reading and Composition (CIRC)}


Efektivitas Model Pembelajaran Tipe Group Investigation (GI) Dan Cooperative Integrated Reading And Composition (CIRC) Dalam Meningkatkan Kreativitas Berpikir Kritis Dan Hasil Belajar IPS Siswa Kelas 4 (Lucia Venda Christina, Firosalia Kristin)

Langkah-langkah pembelajaran dengan menggunakan model CIRC adalah pembentukan kelompok kecil yang terdiri dari 4-5 siswa heterogen, guru memberikan wacana/bacaan sesuai tema, siswa dalam kelompok saling bekerja sama membacakan dan menyampaikan ide/gagasan berdasarkan wacana/bacaan, setiap kelompok menyusun laporan tertulis, presentasi hasil diskusi tiap kelompok, penutup.

\section{Kelebihan dan Kelemahan Model Pembelajaran Cooperative Integrated Reading and Composition (CIRC)}

Kelebihan pembelajaran kooperatif tipe CIRC adalah (1) CIRC sangat tepat untuk meningkatkan keterampilan siswa dalam menyelesaikan soal pemecahan masalah, (2) dominasi guru dalam pembelajaran berkurang, (3) siswa termotivasi pada hasil secara teliti, karena bekerja dalam kelompok, (4) para siswa dapat memahami makna soal dan saling mengecek pekerjaannya, (5) membantu siswa yang lemah, (6) meningkatkan hasil belajar khususnya dalam menyelesaikan soal yang berbentuk pemecahan masalah

Kelemahan model CIRC menurut Slavin yaitu model pembelajaran ini hanya dapat digunakan mata pelajaran yang menggunakan bahasa sehingga mata pelajaran seperti matematika dan pelajaran lain yang menggunakan prinsip menghitung tidak bisa menggunakan model pembelajaran ini karena model ini lebih menekan pada membaca, menulis, dan seni bahasa.

Dari kelemahan di atas maka guru harus menyesesuaikan mata pelajaran, materi, dan model pembelajaran yang akan digunakan. Dan untuk presentasi setiap kelompok, dapat dipilih secara acak agar semua anggota kelompok berusaha untuk menguasai pekerjaannya sehingga tidak hanya siswa yang pintar saja yang mewakili presentasi.

\section{Kreativitas Berpikir Kritis}

\section{Hakikat Berpikir Kritis}

John Dewey dalam Fisher (2008:2) mendefinisikan bahwa berpikir kritis sebagai pertimbangan yang aktif, persistent (terus-menerus), dan teliti mengenai sebuah keyakinan atau bentuk pengetahuan yang diterima begitu saja dipandang dari sudut alasan-alasan yang mendukungnya dan simpulan lanjutan yang menjadi kecenderungannya. Berpikir kritis adalah pemikiran yang masuk akal dan reflektif yang berfokus untuk memutuskan apa yang mesti dipercaya atau dilakukan (Norris dan Ennis dalam Fisher, 2008:4). Jadi, berpikir kritis merupakan kemampuan seseorang dalam menemukan informasi dan pemecahan dari suatu masalah dengan cara bertanya kepada dirinya sendiri untuk menggali informasi tentang masalah yang sedang dihadapi.

\section{Tujuan Berpikir Kritis}

Berpikir kritis di kelas pada saat pembelajaran sudah dimulai ketika seorang siswa berdiskusi dengan anggota kelompoknya. Tujuan berpikir kritis yaitu agar siswa mampu memahami argumentasi-argumentasi yang disampaikan oleh guru dan teman-temannya, supaya siswa mampu menilai argumentasi/pendapat tersebut secara kritis, membangun dan mempertahankan argumen yang dibangun secara sungguh-sungguh dan meyakinkan.

\section{Hasil Belajar \\ Pengertian Hasil Belajar}

Menurut Sudjana (2004:22) hasil belajar adalah kemampuan-kemampuan yang dimiliki siswa setelah ia menerima pengalaman belajarnya. Purwanto (2011:46) menyatakan bahwa hasil belajar 
adalah perubahan perilaku peserta didik akibat belajar. Perubahan perilaku disebabkan karena dia mencapai penguasaan atas sejumlah bahan yang diberikan dalam proses belajar mengajar. Hasil belajar dapat berupa perubahan dalam aspek kognitif, afektif, dan psikomotorik.

Berdasarkan uraian tersebut peneliti menyimpulkan bahwa hasil belajar merupakan perubahan perilaku siswa setelah mengikuti pelajaran terjadi akibat lingkungan belajar yang sengaja dibuat oleh guru melalui model pembelajaran yang dipilih dan digunakan dalam suatu pembelajaran. Pembelajaran akan dikatakan berhasil jika setelah mengikuti pelajaran terjadi perubahan dari dalam diri siswa. Namun jika tidak terjadi perubahan dalam diri siswa maka pembelajaran tersebut belum berhasil.

\section{Faktor yang Mempengaruhi Hasil Belajar}

Faktor yang mempengaruhi hasil belajar yaitu faktor dari dalam diri siswa dan faktor dari luar diri siswa. Faktor dari dalam diri siswa adalah perubahan kemampuan yang dimiliki. Sedangkan faktor dari luar diri siswa yaitu lingkungan yang berupa kualitas pembelajaran (Sudjana, 2004:39).

Dari beberapa uraian diatas maka dapat disimpulkan bahwa faktor yang mempengaruhi hasil belajar siswa terdapat dalam diri siswa yaitu kemampuan dan keinginan yang dimiliki untuk belajar, serta lingkungan sekitar siswa baik lingkungan sosial maupun keadaan yang sengaja dibuat oleh guru untuk mencapai hasil belajar yang diharapkan.

\section{Kajian Hasil Penelitian yang Relevan}

Penelitian yang dilakukan oleh Arfiani Isnaningrum (2013) dengan judul "Peningkatan Kreativitas dan Hasil Belajar IPS Melalui Model Group Investigation Siswa Kelas 4 SD Negeri Kluwan 01 Kab Grobogan Semester 2 Tahun Pelajaran 2012/2013”. Kondisi awal kategori siswa yang tidak kreatif sebanyak 60\%, kategori kurang kreatif sebanyak 40\%, dan kategori kreatif belum ada atau $0 \%$. Pada siklus I 27\% siswa termasuk dalam kategori tidak kreatif, 66\% siswa dalam kategori kurang kreatif, dan belum ada (7\%) siswa yang termasuk dalam kategori kreatif. Selanjutnya pada siklus 2 meningkat, tidak ada kategori siswa tidak kreatif (0\%), kategori kurang kreatif 17\%, dan 83\% siswa dalam kategori kreatif. Peningkatan kreativitas sudah mencapai indikator kinerja yang diharapkan yaitu $80 \%$ dan hasil belajar IPS siswa meningkat menjadi $90 \%$ siswa yang mendapat nilai lebih dari KKM (65).

Gustikasari (2012) melakukan penelitian dengan judul "Peningkatan Aktivitas dan Hasil Belajar Siswa Kelas IV pada Mata Pelajaran IPS Pokok Bahasan Perkembangan Teknologi melalui Penerapan Model Kooperative Tipe CIRC di SDN Kebonsari 03 Jember", pada kondisi awal sebelum dilakukan tindakan menunjukkan aktivitas siswa yang tergolong aktif hanya 9 siswa dengan presentase 25,7\%, 6 siswa $(17,1 \%)$ cukup aktif, 10 siswa $(28,6 \%)$ kurang aktif, dan 10 siswa $(28,6)$ sangat kurang aktif. Setelah di lakukan tindakan terdapat peningkatan terbukti dari presentase aktivitas belajar siswa sebelum tindakan secara klasikal sebesar $39,1 \%$ pada siklus I meningkat menjadi 68,8\% dan meningkat lagi pada siklus II menjadi 73,7\%.

Dengan demikian dapat disimpulkan bahwa hasil penelitian pembelajaran dengan menggunakan model pembelajaran Cooperative Integrated Reading and Composition dan Group Investigation di atas sangat mendukung penelitian eksperimen ini yang bertujuan untuk mengetahui pengaruh model pembelajaran kooperatif tipe Cooperative Integrated Reading and Composition dan Group Investigation terhadap kreativitas berpikir kritis dan hasil belajar IPS.

\section{Hipotesis Penelitian}

Berdasarkan uraian di atas maka hipotesis yang akan diajukan dalam penelitian ini adalah ada perbedaan efektivitas model pembelajaran kooperatif tipe Group Investigation dan Cooperative 
Efektivitas Model Pembelajaran Tipe Group Investigation (GI) Dan Cooperative Integrated Reading And Composition (CIRC) Dalam Meningkatkan Kreativitas Berpikir Kritis Dan Hasil Belajar IPS Siswa Kelas 4 (Lucia Venda Christina, Firosalia Kristin)

Integrated Reading and Composition dengan model ceramah dalam meningkatkan kreativitas berpikir kritis dan hasil belajar IPS siswa kelas 4.

\section{METODE}

Metode penelitian yang dilakukan adalah metode eksperimen. Penelitian eksperimen merupakan penelitian yang dilakukan dengan manipulasi yang bertujuan untuk mengetahui akibat manipulasi terhadap perilaku individu yang diamati (Latipun dalam Soesilo, 2015:1). Desain penelitian yang digunakan penulis dalam penelitian ini mengacu pada desain penelitian menurut Sugiyono (2008:112). Dalam penelitian kelas eksperimen dan kelas kontrol diberi pre-test untuk mengetahui keadaan awal. Setelah diketahui bahwa kedua kelas tersebut sama/homogen kemudian kelas eksperimen diberi treatmen/perlakuan dengan model pembelajaran kooperatif tipe GI dan CIRC sedangkan kelas kontrol menggunakan model pembelajaran konvensional. Selanjutnya pemberian post-test pada kedua kelas untuk mengetahui keefektifan penerapan model pembelajaran kooperatif tipe $G I$ dan $C I R C$ pada pembelajaran IPS kelas 4 SD.

\section{Prosedur Eksperimen}

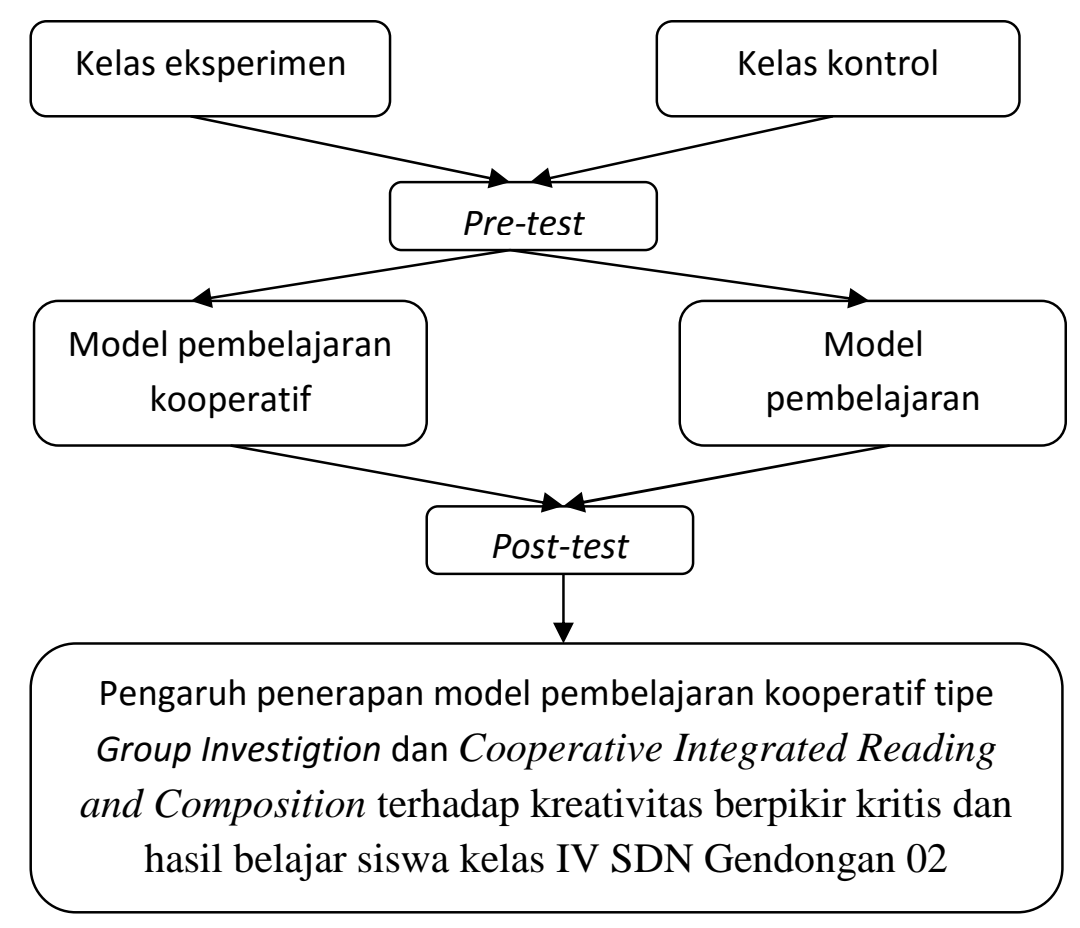

Subjek dalam penelitian ini adalah siswa kelas 4 SDN Gendongan 02 dan siswa kelas 4 SDN Sidorejo Kidul 02 Kota Salatiga semester 2 tahun pelajaran 2015/2016. Sebagai kelas eksperimen adalah siswa kelas 4 SDN Gendongan 02 Salatiga yang berjumlah 37 siswa yang terdiri dari 22 siswa berjenis kelamin perempuan dan 15 siswa brjenis kelamin laki-laki dan sebagai kelas kontrol adalah siswa kelas 4 SDN Sidorejo Kidul 02 yang berjumlah 35 siswa yang terdiri dari 20 siswa berjenis kelamin perempuan dan 15 siswa berjenis kelamin laki-laki.

Menurut Sugiyono (2011:308) teknik pengumpulan data merupakan langkah yang paling utama dalam penelitian, karena tujuan dari penelitian adalah mendapatkan data. Teknik pengumpulan data dalam penelitian ini adalah tes. Serta rubrik penilaian untuk mengetahui tingkat kreativitas berpikir kritis siswa. 
Instrumen pengumpulan data yang digunakan dalam penelitian ini adalah tes yang berupa pilihan ganda terdiri dari pretest-posttest dan rubrik penilaian kreativitas berpikir kritis. Hasil dari pre-test dan post-test dapat menunjukkan adanya peningkatan atau penurunan hasil belajar siswa sebelum dan sesudah menerima perlakuan dalam pembelajaran dengan menerapkan model pembelajaran kooperatif tipe GI dan CIRC. Sedangkan rubrik penilaian kreativitas berpikir kritis digunakan untuk melihat kreativitas berpikir kritis siswa kelas 4 pada pembelajaran IPS dengan menggunakan model pembelajaran GI dan CIRC.

Menurut Sugiyono (2012:121) uji validitas adalah ketepatan antara data yang terkumpul dengan data yang sesungguhnya terjadi pada obyek yang diteliti. Dalam penelitian ini uji validitas digunakan untuk menguji validitas instrument yang berupa pre-test dan post-test. Penulis menggunakan signifikansi 5\% menurut teori Sugiyono dengan N=40 maka soal akan dikatakan valid apabila nilai korelasinya $>0,312$. Dari uji validitas yang telah dilakukan diketahui jumlah soal yang valid adalah 31 butir dan 9 butir soal tidak valid.Instrumen dapat dikatakan reliabel jika nilai alpha $>0,7$. Uji reliabilitas dapat dilakukan dengan menggunakan SPSS 16.0 melalui langkah Analyze Scale - Reliability Analysis.

\section{HASIL PENELITIAN DAN PEMBAHASAN}

\section{Analisis Instrumen Penelitian}

Instrumen pada penelitian ini adalah tes hasil belajar dan rubrik penilaian untuk mengetahui kreativitas berpikir siswa. Soal tes telah di uji cobakan sebelumnya di SDN Gendongan 02. Hasil uji coba yang didapatkan adalah soal tes yang digunakan sudah memenuhi persyaratan validitas dan reliabilitas. Dari uji validitas didapat 31 soal valid dan 9 soal tidak valid.

Dari uji normalitas data pretest eksperimen yaitu signifikansi data pretest sebesar 0,088 maka data berdistribusi normal karena taraf signifikansi $0,088>0,05$. Sedangkan uji normalitas pretest kelompok kontrol signifikansinya adalah 0,172 yang berarti lebih besar dari 0,05 maka dapat dikatakan normal.

Tabel 1. Hasil Uji Normalitas Pretest Kelompok Eksperimen dan Kelompok Kontrol Tests of Normality

\begin{tabular}{|l|r|r|r|r|r|r|}
\hline & \multicolumn{3}{|c|}{ Kolmogorov-Smirnov $^{\mathrm{a}}$} & \multicolumn{3}{c|}{ Shapiro-Wilk } \\
\cline { 2 - 7 } & Statistic & \multicolumn{1}{c|}{$\mathrm{df}$} & \multicolumn{1}{c|}{ Sig. } & Statistic & \multicolumn{1}{c|}{ df } & \multicolumn{1}{c|}{ Sig. } \\
\hline pretest_kelas_eksperimen & .135 & 37 & .088 & .967 & 37 & .331 \\
pretest_kelas_kontrol & .126 & 35 & .172 & .959 & 35 & .218 \\
\hline
\end{tabular}

Uji homogenitas dapat dilakukan apabila data kedua kelas berdistribusi normal. Uji homogenitas dilakukan untuk mengetahui varian antara kelas eksperimen dan kelas kontrol sama atau tidak. Berikut adalah hasil uji homogenitas:

Tabel 2. Hasil Uji Homogenitas

Test of Homogeneity of Variances

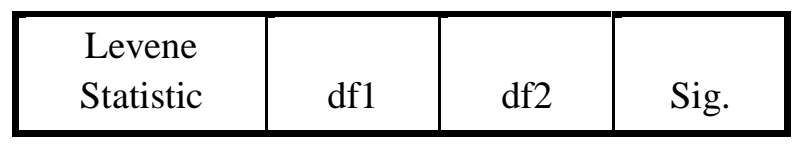


Efektivitas Model Pembelajaran Tipe Group Investigation (GI) Dan Cooperative Integrated Reading And Composition (CIRC) Dalam Meningkatkan Kreativitas Berpikir Kritis Dan Hasil Belajar IPS Siswa Kelas 4 (Lucia Venda Christina, Firosalia Kristin)

Test of Homogeneity of Variances

\begin{tabular}{|c|c|c|c|}
\hline $\begin{array}{l}\text { Levene } \\
\text { Statistic }\end{array}$ & df1 & df2 & Sig. \\
\hline .055 & 1 & 70 & .815 \\
\hline
\end{tabular}

Hasil uji homogenitas nilai pretest kedua kelas menunjukkan taraf signifikansinya sebesar 0,815 lebih besar dari 0,05 maka kedua kelas tersebut memiliki varian yang sama atau homogen.

\section{Analisis Deskriptif}

Analisis deskriptif digunakan untuk menganalisis data yang sudah dikumpulkan, ukuran yang digunakan adalah mean, standar deviasi, serta nilai maksimal dan minimal. Nilai rata-rata pretest kelas eksperimen yaitu 67,16 dan rata-rata nilai posttest adalah 74,59. Hasil penghitungan dapat dilihat pada tabel berikut:

Tabel 3. Hasil Uji Deskriptif Statistik Pretest Kelas Eksperimen dan Kelas Kontrol Descriptive Statistics

\begin{tabular}{|l|r|r|r|r|r|}
\hline & $\mathrm{N}$ & Minimum & Maximum & Mean & Std. Deviation \\
\hline pretest_eksperimen & 37 & 50 & 90 & 67.16 & 9.618 \\
pretest_kontrol & 35 & 40 & 73 & 51.54 & 12.504 \\
Valid N (listwise) & 35 & & & & \\
\hline
\end{tabular}

Tabel 4. Hasil Uji Deskriptif Statistik Posttest Kelas Eksperimen dan Kelas Kontrol Descriptive Statistics

\begin{tabular}{|l|r|r|r|r|r|}
\hline & \multicolumn{1}{|c|}{ N } & Minimum & Maximum & Mean & Std. Deviation \\
\hline posttest_eksperimen & 37 & 56 & 93 & 74.59 & 10.898 \\
posttest_kontrol & 35 & 43 & 76 & 57.46 & 14.696 \\
Valid N (listwise) & 35 & & & & \\
\hline
\end{tabular}

Kreativitas berpikir kritis pada pembelajaran IPS siswa kelas 4 SDN Gendongan 02 dengan menggunakan model pembelajaran GI dan CIRC terbukti nilai rata-rata kreativitas berpikir kritis lebih tinggi dibandingkan dengan kreativitas berpikir kritis kelas kontrol. Nilai rata-rata berpikir kritis kelas eksperimen yaitu 29,32 sedangkan nilai rata-rata berpikir kritis kelas kontrol adalah 28,05. Hasil penghitungan data dapat dilihat pada tabel dibawah ini.

Tabel 5. Hasil Uji Deskriptif Statistik Kreativitas Berpikir Kritis Kelas Eksperimen Descriptive Statistics

\begin{tabular}{|l|l|l|l|l|l|}
\hline & $\mathrm{N}$ & Minimum & Maximum & Mean & Std. Deviation \\
\hline
\end{tabular}




\begin{tabular}{|c|c|c|c|c|c|}
\hline $\begin{array}{l}\text { kreativitas_berpikir_kriti } \\
\text { s } \\
\text { Valid N (listwise) }\end{array}$ & $\begin{array}{l}37 \\
37\end{array}$ & 24 & 36 & 29.32 & 2.583 \\
\hline
\end{tabular}

Tabel 6. Hasil Uji Deskriptif Statistik Kreativitas Berpikir Kritis Kelas Kontrol Descriptive Statistics

\begin{tabular}{|c|c|c|c|c|c|}
\hline & $\mathrm{N}$ & Minimum & Maximum & Mean & Std. Deviation \\
\hline $\begin{array}{l}\text { kreativitas_berpikir_kritis } \\
\text { _kontrol }\end{array}$ & 35 & 21 & 31 & 28.05 & 2.5 \\
\hline Valid N (listwise) & 35 & & & & \\
\hline
\end{tabular}

\section{Analisis Uji T}

Uji T dalam penelitian ini bertujuan untuk mengetahui signifikansi koefisien post-test kedua kelompok dan selisih nilai pretest-posttest dengan menggunakan uji dua sampel tidak berhubungan (Independent Samples T Test). Uji T digunakan untuk mengetahui ada atau tidaknya pengaruh positif dan signifikansi penerapan model pembelajaran kooperatif tipe group investigation dan cooperative integrated reading and composition yang dibandingkan dengan penerapan model pembelajaran konvensional terhadap kreativitas berpikir kritis dan hasil belajar IPS siswa kelas 4 yang dilihat dari selisih rata-rata antara pretest dan posttest kedua kelompok sampel di analisis dengan uji t. Hasil penghitungan dapat diketahui dengan melakukan uji $\mathrm{T}$.

Tabel 7. Hasil Uji T Pretest-Posttest Kedua Sampel

Independent Samples Test

\begin{tabular}{|c|c|c|c|c|c|c|c|c|c|}
\hline & \multicolumn{2}{|c|}{$\begin{array}{c}\text { Levene's } \\
\text { Test for } \\
\text { Equality of } \\
\text { Variances }\end{array}$} & \multicolumn{7}{|c|}{ t-test for Equality of Means } \\
\hline & \multirow[b]{2}{*}{$\mathrm{F}$} & \multirow[b]{2}{*}{ Sig. } & \multirow[b]{2}{*}{$\mathrm{T}$} & \multirow[b]{2}{*}{ Df } & \multirow{2}{*}{$\begin{array}{c}\text { Sig. } \\
(2- \\
\text { tailed } \\
)\end{array}$} & \multirow{2}{*}{$\begin{array}{c}\text { Mean } \\
\text { Differenc } \\
\mathrm{e}\end{array}$} & \multirow{2}{*}{$\begin{array}{l}\text { Std. Error } \\
\text { Difference }\end{array}$} & \multicolumn{2}{|c|}{$\begin{array}{l}\text { 95\% Confidence } \\
\text { Interval of the } \\
\text { Difference }\end{array}$} \\
\hline & & & & & & & & Lower & Upper \\
\hline $\begin{array}{ll}\text { nila } & \text { Equal } \\
\text { i } & \text { variances } \\
& \text { assumed }\end{array}$ & 6.177 & .015 & 5.722 & 70 & .000 & 15.666 & 2.738 & 10.206 & 21.126 \\
\hline $\begin{array}{l}\text { Equal } \\
\text { variances } \\
\text { not assumed }\end{array}$ & & & 5.675 & 62.342 & .000 & 15.666 & 2.761 & 10.148 & 21.183 \\
\hline
\end{tabular}

Tabel 8. Hasil Uji T Kreativitas Berpikir Kritis Independent Samples Test 
Efektivitas Model Pembelajaran Tipe Group Investigation (GI) Dan Cooperative Integrated Reading And Composition (CIRC) Dalam Meningkatkan Kreativitas Berpikir Kritis Dan Hasil Belajar IPS Siswa Kelas 4 (Lucia Venda Christina, Firosalia Kristin)

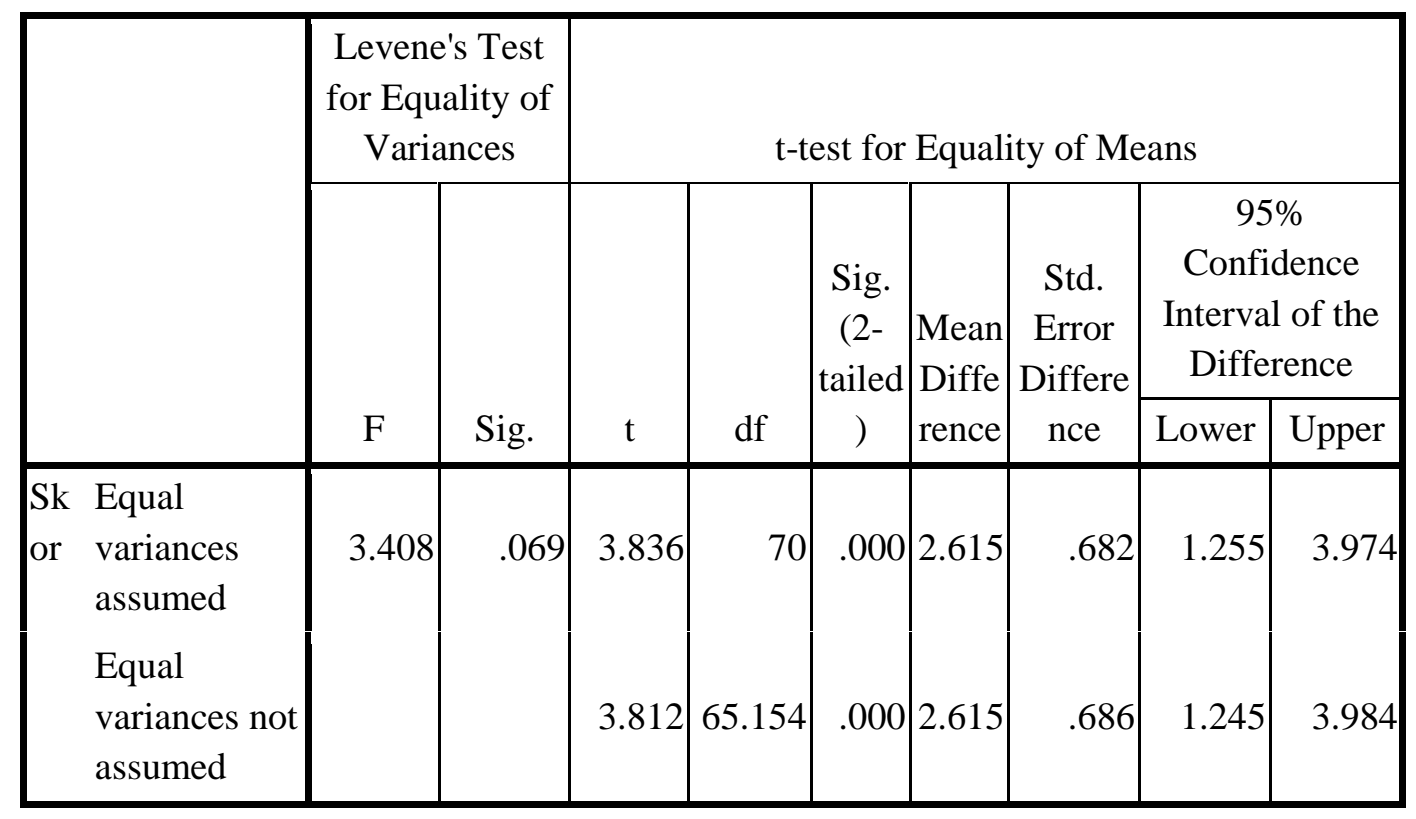

Berdasarkan tabel 8 didapat $\mathrm{t}$ hitung sebesar 5,722 dan $\mathrm{t}$ tabel 0,05, maka dapat dikatakan Ho ditolak karena signifikansinya 0,000 atau tidak lebih besar dari 0,05. Hasil uji t penilaian kreativitas berpikir kritis siswa menunjukkan bahwa $\mathrm{t}$ hitung sebesar 3,836 dan $\mathrm{t}$ tabel 0,05 , maka dapat dikatakan Ho ditolak karena signifikansinya $0,000<0,05$ sehingga terdapat pengaruh penerapan model pembelajaran kooperatif tipe group investigation dan cooperation integrated and reading composition dalam meningkatkan kreativitas berpikir kritis dan hasil belajar IPS siswa kelas 4 SDN Gendongan 02. Dikatakan efektif karena terdapat pengaruh perbedaan penerapan model pembelajaran tersebut.

Jadi, dapat disimpulkan bahwa penerapan model pembelajaran group investigation dan cooperation integrated and reading composition dapat meningkatkan kreativitas berpikir kritis dan hasil belajar IPS dibandingkan dengan model konvensional atau ceramah.

\section{Pembahasan}

Penelitian eksperimen ini dilakukan di dua SD yaitu SDN Gendongan 02 sebagai kelas eksperimen dan SDN Sidorejo Kidul 02 sebagai kelas kontrol. Dari hasil uji normalitas data pretest kelompok eksperimen signifikansi adalah 0,88>0,05. Maka dapat diambil kesimpulan data dari kelompok eksperimen berdistribusi normal. Untuk uji normalitas data pretest kelompok kontrol diperoleh sigifikansi 0,172>0,05. Jadi, dapat diambil kesimpulan bahwa data dari kelompok kontrol berdistribusi normal.

Penelitian eksperimen ini menggunakan model pembelajaran kooperatif tipe GI dan CIRC pada kelas eksperimen yang dibandingkan dengan model pembelajaran konvensional atau ceramah pada kelas kontrol.

Menurut Slavin (2005:218), pembelajaran dengan menggunakan model pembelajaran kooperatif tipe group investigation membuat siswa lebih aktif dan dapat memahami materi pelajaran. Siswa lebih mengerti apa yang dipelajari karena siswa menemukan sendiri jawaban atas pertanyaanpertanyaan berdasarkan suatu topik dilingkungannya untuk kemudian diteliti kebenarannya secara kelompok, hal ini didukung dengan situasi pembelajaran yang menyenangkan.

Menurut Slavin (2005:200) CIRC merupakan program yang komprehensif untuk mengajari pembelajaran membaca, menulis, dan seni bahasa pada kelas yang lebih tinggi di sekolah dasar. CIRC memiliki tiga prinsip dasar yaitu kemampuan membaca pemahaman, membaca lisan, dan integrasi 
seni berbahasa atau menulis. Sehingga siswa akan lebih senang dan aktif dalam mengikuti pembelajaran. Sedangkan pembelajaran dengan model pembelajaran konvensional atau ceramah akan membuat siswa kurang aktif dan siswa kurang antusias untuk mengikuti pembelajaran.

Berdasarkan hasil analisis uji $\mathrm{t}$ data pretest dan posttest kedua kelompok sampel diketahui bahwa signifikansi keduanya adalah 0,000 atau tidak lebih besar dari 0,05 dan thitung sebesar 5,722 sedangkan t tabel diketahui 0,05 . Hasil uji t penilaian kreativitas berpikir kritis siswa menunjukkan bahwa $\mathrm{t}$ hitung sebesar 3,836 dan t tabel 0,05, maka dapat dikatakan Ho ditolak karena signifikansinya $0,000<0,05$. Maka Ho ditolak karena $\mathrm{Ho}<0,05$ dan Ha diterima yang berarti terdapat perbedaan pengaruh positif dan keefektivitasan penerapan model pembelajaran group investigation dan cooperative integrated reading and composition pada kelas eksperimen. Uji deskriptif data rubrik kreativitas berpikir kritis menunjukkan bahwa kemampuan berpikir kritis siswa SDN Gendongan 02 dengan diterapkannya model pembelajaran group investigation dan cooperative integrated reading and composition pada pembelajaran IPS kelas 4 semester 2 sebesar 29,32, sedangkan pada kelas kontrol sebesar 28,05.

Penelitian yang dilakukan oleh Arfiani Isnaningrum (2013) dengan judul "Peningkatan Kreativitas dan Hasil Belajar IPS Melalui Model Group Investigation Siswa Kelas 4 SD Negeri Kluwan 01 Kab Grobogan Semester 2 Tahun Pelajaran 2012/2013”. Mendukung hasil penelitian ini karena dalam penelitiannya menunjukkan bahwa peningkatan kreativitas sudah mencapai indikator kinerja yang diharapkan yaitu $80 \%$ dan hasil belajar IPS siswa meningkat menjadi $90 \%$ siswa yang mendapat nilai lebih dari KKM (65).

Dari beberapa teori dan kajian hasil penelitian yang relevan mendukung hasil penelitian ini. Berdasarkan hasil analisis uji $\mathrm{t}$ dan signifikansi di atas yaitu Ho ditolak yang berarti bahwa terdapat perbedaan pengaruh positif dan signifikan penerapan model pembelajaran kooperatif tipe $G I$ dan CIRC dengan model pembelajaran ceramah terhadap kreativitas berpikir kritis dan hasil belajar IPS siswa kelas 4.

Jadi, dapat disimpulkan bahwa penerapan model pembelajaran kooperatif tipe group investigation dan cooperative integrated reading and composition lebih efektif dalam meningkatkan kreativitas berpikir kritis dan hasil belajar IPS siswa kelas 4 dibandingkan dengan model pembelajaran konvensional.

\section{SIMPULAN DAN SARAN}

\section{Simpulan}

Berdasarkan hasil analisis dan pembahasan hasil penelitian pada bab sebelumnya, maka dapat disimpulkan bahwa penerapan model pembelajaran kooperatif tipe GI dan CIRC dalam pembelajaran IPS kelas 4 SDN Gendongan 02 efektif dalam meningkatkan kreativitas berpikir kritis.

Penerapan model pembelajaran kooperatif tipe GI dan CIRC tidak hanya efektif dalam meningkatkan kreativitas berpikir kritis saja. Dalam penelitian ini didapat hasil bahwa penerapan model pembelajaran kooperatif tipe GI dan CIRC dalam pembelajaran IPS kelas 4 SDN Gendongan 02 efektif dalam meningkatkan hasil belajar.

\section{Saran}

Berdasarkan hasil penelitian terbukti bahwa penerapan model pembelajaran kooperatif tipe group investigation dan cooperative integrated reading and composition efektif dalam meningkatkan kreativitas berpikir kritis dan hasil belajar IPS, maka saran yang diajukan adalah sebagai berikut: 
Efektivitas Model Pembelajaran Tipe Group Investigation (GI) Dan Cooperative Integrated Reading And Composition (CIRC) Dalam Meningkatkan Kreativitas Berpikir Kritis Dan Hasil Belajar IPS Siswa Kelas 4 (Lucia

Venda Christina, Firosalia Kristin)

1. Bagi guru hendaknya Guru dapat menerapkan model pembelajaran GI dan CIRC sebagai alternatif metode pengajaran pada mata pelajaran IPS karena model ini sudah terbukti efektif untuk meningkatkan kreativitas berpikir kritis dan hasil belajar IPS.

2. Bagi siswa hendaknya lebih aktif dan membiasakan diri berpikir kritis untuk menemukan jawaban dari soal dan pertanyaan yang diberikan serta tidak pasif.

3. Bagi sekolah agar menyediakan sarana dan prasarana yang diperlukan untuk pembelajaran sehingga dapat mendukung pembelajaran.

4. Bagi pembaca, apabila akan melakukan penelitian dengan model yang sama hendaknya pemilihan kelompok ditentukan oleh guru.

\section{DAFTAR PUSTAKA}

Arikunto, Suharsimi. 2005. Dasar-dasar Evaluasi Pendidikan (Edisi Revisi). Jakarta: Bumi Aksara.

Gustikasari. 2012. Skripsi. Peningkatan Aktivitas dan Hasil Belajar Siswa Kelas IV pada Mata Pelajaran IPS Pokok Bahasan Perkembangan Teknologi melalui Penerapan Model Kooperative Tipe CIRC di SDN Kebonsari 03 Jember. Skipsi UNEJ.

Hadinata, Benyamin, dkk. 2008. Berpikir Kritis: Sebuah Pengantar. PT Gelora Aksara Pratama.

Sanjaya, Wina. 2011. Strategi Pembelajaran Berorientasi Standar Proses Pendidikan. Jakarta: Kencana Perdana Media.

Sarwono, Jonathan. 2009. Statistik Itu Mudah: Panduan Lengkap Untuk Belajar Komputasi Statistik Menggunakan SPSS 16. Yogyakarta: C.V Andi Offiser.

Slavin R.E. 2005. Cooperative Learning Teori, Riset dan Praktik. Bandung: Nusa Media.

Soesilo, Tritjahjo Danny. 2015. Penelitian Eksperimen. Salatiga: Griya Media.

Sudjana, Nana. 2009. Penilaian Hasil Proses Belajar Mengajar. Bandung: PT Remaja Rosdakarya

Sugandi, Achmad, dkk. 2000. Belajar dan Pembelajaran. Semarang: IKIP PRESS. http://www.sarjanaku.com/2012/11/pengertian-pembelajaran-menurut-para-ahli.html. Diakses pada 2 Maret 2016.

Suprijono, Agus. 2009. Cooperative Learning Teori dan Aplikasi PAIKEM. Yogyakarta: Pustaka Belajar.

Suprijono, Agus. 2011. Cooperative learning. Yogyakarta: Pustaka Belajar.

Sutrisno, Leo. 2008. Hasil Belajar. http://www.scribd.com/ doc/ 49860484/ 14/ pengertian-hasilbelajar. Diakses pada 2 Maret 2016.

Widiarto, Tri. 2007. Pendidikan IPS (Konsep Dasar IPS). Salatiga: Widya Sari Press.

Widoyoko, Eko Putro. 2015. Teknik Penyusunan Instrumen Penelitian. Yogyakarta: Pustaka Belajar. 